\title{
Green and blue water footprint reduction in irrigated agriculture: effect of irrigation techniques, irrigation strategies and mulching
}

\author{
A. D. Chukalla, M. S. Krol, and A. Y. Hoekstra \\ Twente Water Centre, University of Twente, Enschede, the Netherlands \\ Correspondence to: A. D. Chukalla (a.d.chukalla@utwente.nl)
}

Received: 16 June 2015 - Published in Hydrol. Earth Syst. Sci. Discuss.: 23 July 2015

Revised: 6 November 2015 - Accepted: 7 December 2015 - Published: 21 December 2015

\begin{abstract}
Consumptive water footprint (WF) reduction in irrigated crop production is essential given the increasing competition for freshwater. This study explores the effect of three management practices on the soil water balance and plant growth, specifically on evapotranspiration (ET) and yield $(Y)$ and thus the consumptive WF of crops (ET/ $Y$ ). The management practices are four irrigation techniques (furrow, sprinkler, drip and subsurface drip (SSD)), four irrigation strategies (full (FI), deficit (DI), supplementary (SI) and no irrigation), and three mulching practices (no mulching, organic (OML) and synthetic (SML) mulching). Various cases were considered: arid, semi-arid, sub-humid and humid environments in Israel, Spain, Italy and the UK, respectively; wet, normal and dry years; three soil types (sand, sandy loam and silty clay loam); and three crops (maize, potato and tomato). The AquaCrop model and the global WF accounting standard were used to relate the management practices to effects on ET, $Y$ and WF. For each management practice, the associated green, blue and total consumptive WF were compared to the reference case (furrow irrigation, full irrigation, no mulching). The average reduction in the consumptive WF is $8-10 \%$ if we change from the reference to drip or SSD, $13 \%$ when changing to OML, $17-18 \%$ when moving to drip or SSD in combination with OML, and $28 \%$ for drip or SSD in combination with SML. All before-mentioned reductions increase by one or a few per cent when moving from full to deficit irrigation. Reduction in overall consumptive WF always goes together with an increasing ratio of green to blue WF. The WF of growing a crop for a particular environment is smallest under DI, followed by FI, SI and rain-fed. Growing crops with sprinkler irrigation has the largest consumptive WF, followed by furrow, drip and SSD. Furrow irrigation has a smaller consumptive WF compared with sprinkler,
\end{abstract}

even though the classical measure of "irrigation efficiency" for furrow is lower.

\section{Introduction}

One of the important prospects for relieving increasing water scarcity is to reduce the consumptive water use in the agricultural sector, which makes up the largest share in global freshwater consumption (Hoekstra and Mekonnen, 2012). In crop production substantial gains can be achieved by increasing yield and reducing water losses, with the latter referring to the non-beneficial consumptive water use at field level and the non-recoverable losses at system level (Steduto et al., 2007; Hoekstra, 2013; Perry et al., 2009; Falkenmark and Rockström, 2006). At field level, the focus is to decrease the field evapotranspiration (ET) over the growing period per unit of yield $(Y)$, a ratio that is called the consumptive water footprint (WF) (Hoekstra et al., 2011). Decreasing this $\mathrm{ET} / Y$ ratio is the same as increasing the inverse $(Y / \mathrm{ET})$, which is called the water productivity (WP) (Amarasinghe and Smakhtin, 2014; Molden et al., 2010).

The soil moisture status in the root zone regulates plant growth and influences ET. Management practices that influence soil moisture include irrigation techniques, irrigation strategies and mulching practices. The particular irrigation technique influences the way irrigation water is applied, which influences for instance the percentage of surface wetting, which again influences ET (Raes et al., 2013). The particular irrigation strategy applied determines how much and when irrigation is applied. The mulching practice determines soil cover and in this way influences non-productive evaporation. 
Various previous studies considered the effects of management practices on the amount of irrigation water to be applied, drainage, ET and yield (Gleick, 2003; Perry et al., 2007, 2009). Most studies varied only irrigation technique, only irrigation strategy or only mulching practice, or considered only a few combinations. Besides, most studies are confined to just one crop and one specific production environment (soil, climate). For example, Rashidi and Keshavarzpour (2011) show the effects of three management practices for one specific crop in Iran, showing yields as increasing from surface irrigation to drip irrigation and finally to drip irrigation with mulching. Al-Said et al. (2012) show the effect of drip versus sprinkler irrigation on vegetable yield in Oman, showing that the yield per unit of irrigation water applied is higher for drip irrigation. The effects of irrigation strategies such as deficit or supplementary irrigation on ET and $Y$ were studied by different scholars (Igbadun et al., 2012; Qiu and Meng, 2013; Jiru and Van Ranst, 2010; Bakhsh et al., 2012; Jinxia et al., 2012). In a literature review, Geerts and Raes (2009) point out that deficit irrigation strategy decreases the consumptive water use per unit of yield compared to full irrigation. Supplementary irrigation is a strategy to apply some irrigation water when most needed, to overcome drought periods; this increases yield compared to rain-fed conditions without much increase in ET (Oweis and Hachum, 2006; Oweis et al., 1999; Tadayon et al., 2012). Mulching is a method of covering the soil surface that otherwise loses moisture through evaporation. Various studies show the importance of mulching to decrease ET per unit yield in crop production (Ogban et al., 2008; Zhao et al., 2003; Zhou et al., 2011; Mao et al., 2012; Jalota and Prihar, 1998).

Previous studies can be divided into two categories: they either focus on the relation between $Y$ and blue water applied (irrigation water applied) or on the relation between $Y$ and total transpiration $(T)$ or total ET. The former category of studies has two caveats: they ignore green water use and, by focussing on irrigation water application, they ignore the fact that, through return flow (drainage and surface runoff), some of the blue water applied will return to the water system from which it was withdrawn. The caveat of the latter category of studies is that, by considering total $T$ or ET, they do not explicitly distinguish between $T$ or ET from rainwater (green $T$ or ET) and $T$ or ET from irrigation water (blue $T$ or ET). Understanding water resource use in crop production by source (rainwater, irrigation water from surface and groundwater, water from capillary rise) is vital for water resource management. In this regard, the concepts of green versus blue water by Falkenmark and Rockström (2006) and green versus blue water footprint by Hoekstra et al. (2011) are a useful advance.

The objective of this study is to explore the potential of reducing the green and blue water footprint of growing crops by using a systematic model-based assessment of management practices in different environments. We systematically consider the effect of a large number of management practices, considering four irrigation techniques, four irrigation strategies and three mulching practices. We do so in a large number of different cases: arid, semi-arid, sub-humid and humid environments; wet, normal and dry years; three soil types; and three crops. This is the first systematic model study analysing the effect of field management practices on green and blue ET, $Y$ and green and blue WF under a variety of conditions. The advantage of a model study is that field experiments on the effects of a comprehensive list of management practices in a range of cases would be laborious and expensive (Geerts and Raes, 2009). Our cases, however, are based on four real environments, in Israel, Spain, Italy and the UK.

\section{Method and data}

\subsection{Soil water balance and crop growth modelling}

To balance simplicity, accuracy and robustness of simulating soil water balance, crop growth and yield process, we use the AquaCrop model (version 4.1) (Steduto et al., 2009a). AquaCrop is available as standalone Windows-based software and as a plug-in to GIS software; both run with daily time steps using either calendar or thermal time (Raes et al., 2011). In this study, the plug-in version was applied with daily thermal time.

AquaCrop keeps track of the soil water balance over time by simulating the incoming and outgoing water fluxes with well-described subroutines. The AquaCrop model enables one to simulate various degrees of water supply to the plant, varying from rain-fed and supplementary irrigation to deficit and full irrigation. AquaCrop considers capillary rise to the root zone from shallow groundwater. It estimates capillary rise based on the depth of the water table and two parameters that are specific to hydraulic and textural characteristics of the soil (Raes et al., 2012). The two parameters are estimated for different textural classes of the soil that have similar water retention curves. The capillary rise from AquaCrop is comparable with the estimate from the UPFLOW model, using the Darcy equation and relating matric potential to hydraulic conductivity (Fereres et al., 2012). Water limitations on plant growth are modelled through three sorts of water stress response: canopy expansion rate, stomatal closure and senescence acceleration (Steduto et al., 2009b).

The crop growth engine of AquaCrop first estimates the biomass $(B)$ from a water productivity parameter (WP) and transpiration $(T): B=\mathrm{WP} \times \Sigma T$. The harvestable portion of the biomass (yield $Y$ ) is then determined by multiplying biomass by a crop-specific harvest index (HI): $Y=B \times \mathrm{HI}$. WP is the water productivity parameter in $\mathrm{kg}$ (biomass) per $\mathrm{m}^{2}$ (land area) per $\mathrm{mm}$ (water transpired), normalized for atmospheric evaporative demand and atmospheric $\mathrm{CO}_{2}$ concentration (Steduto et al., 2009a). The modelling of biomass 
water productivity (WP), which remains constant for a given crop species after normalization, forms the core of the AquaCrop growth engine (Steduto et al., 2007; Raes et al., 2009).

AquaCrop separates the actual evapotranspiration (ET) into non-productive and productive water fluxes, viz. soil evaporation $(E)$ and crop transpiration $(T)$. Hence, AquaCrop can simulate the effect of the management practices on these two types of consumptive water use distinctively.

AquaCrop calculates soil evaporation $(E)$ by multiplying the evaporative power of the atmosphere $\left(\mathrm{ET}_{\mathrm{o}}\right)$ by factors that consider the effect of water stress, and the fraction of the soil surface not covered by canopy. Crop canopy expands from the initial canopy cover, which is the product of plant density and the size of the canopy cover per seedling. The canopy is considered in the evaporation calculation after adjustment for micro-advective effects. The soil moisture conditions determine evaporation from the soil surface not covered by canopy in two stages. In the first stage, when the soil surface is wetted by rainfall or irrigation, the evaporation rate is fully determined by the energy available for soil evaporation until the readily evaporable water. In the second stage, the falling rate stage, the evaporation is not only determined by the available energy, but also depends on the hydraulic properties of the soil. The two-stage approach for calculating evaporation is described in detail and validated in Ritchie (1972), who confirmed the ability of the method to predict evaporation for a wide variety of soil types and climatic conditions.

The soil evaporation is adjusted for withered canopy, mulches and partial wetting by irrigation. The AquaCrop model simulates the effect of mulching on evaporation and represents effects of soil organic matter through soil hydraulic properties influencing the soil water balance. Soil evaporation under mulching practice is simulated by correcting $\mathrm{E}$ with a factor that is described by two variables (Raes et al., 2013): soil surface covered by mulch (from 0 to $100 \%)$; and mulch material $\left(f_{\mathrm{m}}\right)$. Quoting the paper by Allen et al. (1998), the values of the parameters for mulch material $\left(f_{m}\right)$ are suggested to vary between 0.5 for mulches of plant material and close to 1.0 for plastic mulches (Raes et al., 2013). The correction factor for mulching is calculated as

Correction factor for mulching $=$

$$
\left(1-f_{\mathrm{m}} \frac{\text { percent covered by mulch }}{100}\right) \text {. }
$$

Soil evaporation is also corrected with a factor that is equivalent to the fraction of the surface wetted by irrigation. The adjustment for partial wetting is not applied when the soil surface is wetted by rain. If the soil surface is covered by mulches and at the same time partially wetted by irrigation, only one of the correction factors, the minimum value of the two, is applied.

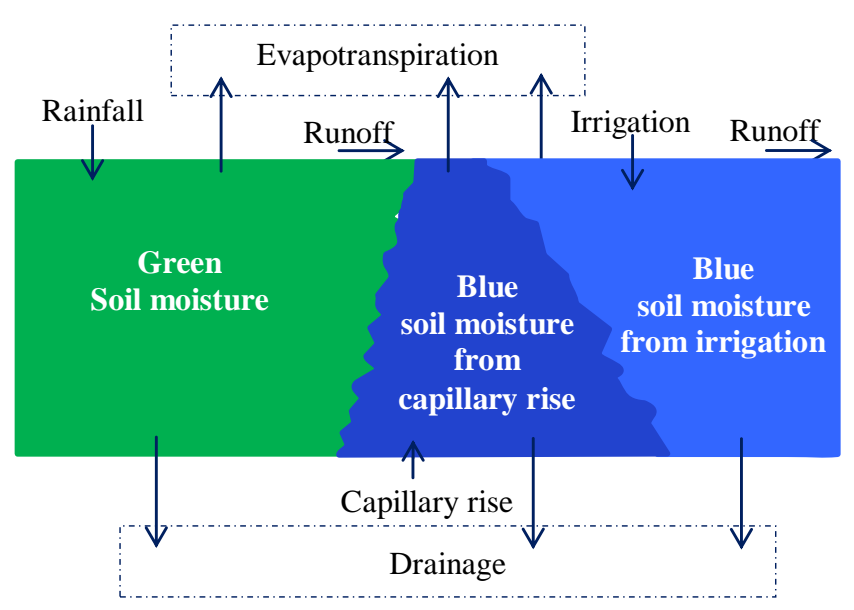

Figure 1. Incoming and outgoing water fluxes of the green $\left(S_{\mathrm{g}}\right)$ and blue $\left(S_{\mathrm{b}}=S_{b-I}+S_{\mathrm{b}-\mathrm{CR}}\right)$ soil water stocks.

Experimental field studies confirm the ability of the AquaCrop model to reasonably simulate evaporation and transpiration for various conditions. Research on potato for three levels of irrigation $(100,75$ and $50 \%$ of plant water requirement) at experimental fields in eastern Iran shows that AquaCrop has good ability in simulating evaporation and transpiration of crops and yield (Afshar and Neshat, 2013). Another study found that AquaCrop is able to simulate ET and yield of maize under different irrigation regimes (full and deficit) and mulching practices (plastic and organic mulching) in the North Delta of Egypt (Saad et al., 2014).

\subsection{The green and blue water footprint of growing crops}

The green WF $\left(\mathrm{m}^{3} \mathrm{t}^{-1}\right)$ and blue WF $\left(\mathrm{m}^{3} \mathrm{t}^{-1}\right)$ of crops were obtained following the definitions and methodological framework of the global WF accounting standard (Hoekstra et al., 2011). They are calculated by dividing the green ET $\left(\mathrm{m}^{3} \mathrm{ha}^{-1}\right)$ and blue ET $\left(\mathrm{m}^{3} \mathrm{ha}^{-1}\right)$ over the growing season by the marketable crop yield $(t)$. AquaCrop simulates a yield in $\mathrm{kg} \mathrm{ha}^{-1}$ of dry matter. Unlike maize, the marketable yields for tomato and potato are in their fresh form. We calculated the marketable yields of tomato and potato by assuming the dry matter of tomato and potato to be 7 and $25 \%$, respectively (Steduto et al., 2012). The AquaCrop output was postprocessed to partition soil water content and the various ingoing and outgoing water fluxes into green and blue components. In addition, the blue soil water content and the blue water fluxes were further separated into blue water originating from irrigation water $\left(S_{\mathrm{b}-I}\right)$ and blue water originating from capillary rise $\left(S_{\mathrm{b}-\mathrm{CR}}\right)$. This partitioning enables us to track which fractions of ET originate from rainwater, irrigation water and capillary rise, respectively (Fig. 1).

In the daily green-blue soil water balance calculation, the next procedures are followed: rainfall $(R)$ adds to the green 
soil water stock; irrigation $(I)$ adds to the blue soil water stock originating from irrigation; capillary rise (CR) adds to the blue soil water stock originating from capillary rise; evaporation $(E)$, transpiration $(T)$ and drainage (Dr) on a certain day are partitioned into the three "colours" (green, blue from irrigation, blue from capillary rise) based on the relative colour composition of soil water content on that day; runoff (RO) in a particular day is partitioned into two colours (green and blue from irrigation) in proportion to the amount of rainfall and irrigation, respectively. Changes in the green $\left(S_{\mathrm{g}}\right)$, blue from irrigation $\left(S_{\mathrm{b}-I}\right)$ and blue from capillary rise $\left(S_{\mathrm{b}-\mathrm{CR}}\right)$ soil water stocks are described in the following three equations:

$$
\begin{aligned}
& \frac{\mathrm{d} S_{\mathrm{g}}}{d \mathrm{t}}=R-(\mathrm{Dr}+\mathrm{ET})\left(\frac{S_{\mathrm{g}}}{S}\right)-\mathrm{RO}\left(\frac{R}{I+R}\right), \\
& \frac{\mathrm{d} S_{\mathrm{b}-\mathrm{CR}}}{\mathrm{d} t}=\mathrm{CR}-(\mathrm{Dr}+\mathrm{ET})\left(\frac{S_{\mathrm{b}-\mathrm{CR}}}{S}\right), \\
& \frac{\mathrm{d} S_{\mathrm{b}-I}}{\mathrm{~d} t}=I-(\mathrm{Dr}+\mathrm{ET})\left(\frac{S_{\mathrm{b}-I}}{S}\right)-\mathrm{RO}\left(\frac{I}{I+R}\right),
\end{aligned}
$$

where $\mathrm{d} t$ is the time step of the calculation (1 day), $R$ rainfall $(\mathrm{mm}), I$ irrigation $(\mathrm{mm})$, RO surface runoff $(\mathrm{mm})$, ET $(\mathrm{E}+\mathrm{T})$ evapotranspiration $(\mathrm{mm})$, Dr drainage (percolation) $(\mathrm{mm})$, and CR capillary rise $(\mathrm{mm})$.

The simulations with AquaCrop were initialized with typical soil moisture content. This was determined by running the model for each case for a successive period of 20 years (1993 to 2012) and taking the average soil moisture content at the start of the growing period over the full period as the initial condition for another run for the same period of 20 years. We did this iteratively until the 20 -year average output stabilized. We thus used the 20 -year average soil moisture content at the start of the growing season as an initial condition for our simulations. The partitioning of the soil moisture content into green and blue water components was initialized based on a similar procedure. The green and blue water footprints were finally calculated by dividing the green and blue ET over the growing period by the yield.

In the Appendix we provide an illustration of the simulation of green and blue soil moisture content over time for a specific case.

\subsection{Experimental set-up}

A comprehensive set of simulations was carried out, applying different management practices in an extensive number of cases (Table 1).

\subsubsection{Management practices}

\section{Irrigation techniques}

Irrigation techniques can be classified based on various themes: energy or pressure required, how or where the irrigation water is applied, and wetted area by irrigation (Ali,
2011). Based on the wetted surface area, irrigation techniques can be listed as flood irrigation, trickle or localized irrigation and sprinkler irrigation. The first of these, flood irrigation, comprises furrow, border and basin irrigation. The second, trickle irrigation comprises drip and subsurface drip. Given the existing irrigation practices in the four environments that we consider, we analyse four irrigation techniques: furrow (with $80 \%$ surface wetting), sprinkler (100\% surface wetting), drip (30\% wetting) and subsurface drip ( $0 \%$ wetting). Generic assumptions have been made about the specific details of the different irrigation techniques, following default settings in the model. For furrow irrigation, an $80 \%$ wetting percentage is assumed to be representative of every furrow (narrow bed) from the indicative range of 60 to $100 \%$ in the AquaCrop manual (Raes et al., 2013). Alternative field management choices would connect to other (lower) wetting percentages: alternated furrow (30 to 50\%) and every furrow for wide beds (40 to $60 \%$ ).

\section{Irrigation strategies}

Irrigation strategy concerns the timing and volume of artificial soil water replenishment. Four irrigation strategies were considered: full irrigation, deficit irrigation, supplementary irrigation and no irrigation (rain-fed). Irrigation scheduling, when and how much to irrigate, is central to defining these irrigation strategies. Full irrigation is an irrigation strategy in which the full evaporative demand is met; this strategy aims at maximizing yield. It was simulated through automatic generation of irrigation requirement for a no water stress condition. AquaCrop simulates water stress response for three thresholds of soil moisture depletion (Steduto et al., 2009b), relating to affected canopy expansion, stomatal closure and senescence acceleration. The depletion level for minimum stress (effect on canopy expansion) in AquaCrop starts far before the soil moisture depletion reaches $100 \%$ of the readily available moisture water (RAW). The irrigation scheduling in the no water stress condition is crop dependent. The soil moisture was refilled to the field capacity (FC) when 20,36 and $30 \%$ of RAW of the soil is depleted for maize, potato and tomato, respectively (FAO, 2012). This scheduling results in a high irrigation frequency, which is impractical in the case of furrow and sprinkler irrigation. To circumvent such unrealistic simulation for the case of furrow and sprinkler irrigation, we firstly generated the irrigation requirement automatically for a no water stress condition, which obviously results in a high irrigation frequency, especially for course texture soil type. Then the irrigation depths were aggregated and shifted a few days forward, practically allowing more depletion than the no water stress level in such a way that a time gap of a week is maintained between two irrigation events.

Deficit irrigation (DI) is the application of water below the evapotranspiration requirements (Fereres and Soriano, 2007) by limiting water applications, particularly during less 
Table 1. Research model: management practices considered in a number of cases to simulate the effect on ET, $Y$, and consumptive WF.

\begin{tabular}{|c|c|c|}
\hline Management practices & Modelling & Effects \\
\hline $\begin{array}{l}\text { Four irrigation techniques: furrow, sprinkler, } \\
\text { drip and subsurface drip. }\end{array}$ & $\begin{array}{l}\text { Soil water balance } \\
\text { and }\end{array}$ & $\begin{array}{l}\text { - ET } \\
\text { - Yield }\end{array}$ \\
\hline $\begin{array}{l}\text { Three irrigation strategies: full, deficit and } \\
\text { supplementary irrigation; + rain-fed. } \\
\text { Three mulching practices: no mulching, } \\
\text { organic and synthetic mulching. }\end{array}$ & $\begin{array}{l}\text { crop growth model } \\
\text { (AquaCrop) } \\
\text { Global WF } \\
\text { accounting standard }\end{array}$ & - Consumptive WF \\
\hline
\end{tabular}

Cases: four environments (arid, semi-arid, sub-humid and humid), three crops (maize, potato and tomato), three soils (loam, sandy loam and silty clay loam), and three types of years (wet, normal and dry).

drought-sensitive growth stages (English, 1990). The deficit strategy is established by reducing the irrigation supply from the full irrigation requirement. We extensively tested various deficit irrigation strategies that fall under two broad categories: (1) regulated deficit irrigation, where a non-uniform water deficit level is applied during the different phenological stages; and (2) sustained deficit irrigation, where water deficit is uniformly distributed over the whole crop cycle. In general, the larger the deficit the smaller the simulated yield, as expected. The non-linear relation between yield and ET (and thus irrigation supply) gives rise to the existence of an optimum, i.e. the deficit irrigation strategy with the lowest consumptive WF in $\mathrm{m}^{3} \mathrm{t}^{-1}$. In the analysis of simulations, the paper used the specific deficit strategy that is optimal according to the model experiments.

Supplementary irrigation (SI) is defined as the application of a limited amount of water to increase and stabilize crop yields when rainfall fails to provide sufficient water for plant growth (Oweis et al., 1999). Supplementary irrigation was simulated to be a one-time event of refilling the root zone to field capacity when $100 \%$ of the RAW was depleted or when the threshold for stomata closure was triggered.

\section{Mulching practices}

Mulching has various purposes: reduce soil evaporation, control weed incidence and its associated water transpiration, reduce soil compaction, enhance nutrient management and incorporate additional nutrients (McCraw and Motes, 1991; Shaxson and Barber, 2003). The mulching practice in AquaCrop considers mainly evaporation reduction from the soil surface. Three mulching practices were distinguished: no mulching, organic mulching with $f_{\mathrm{m}}=0.5$ and synthetic mulching with $f_{\mathrm{m}}=1$. A mulch cover of $100 \%$ for organic and $80 \%$ for synthetic materials was assumed.

\subsubsection{Cases}

We carry out the model experiments for four different locations: Israel (arid), Spain (semi-arid), Italy (sub-humid) and the UK (humid). Per location we consider wet, normal and dry years, three soil types (loam, sandy loam, silty clay loam), and three crops (maize, potato and tomato). This yields a number of cases as summarized in Table 2 .

\subsection{Data}

The input data to run the AquaCrop were collected for four sites: Eilat in Israel $\left(29.33^{\circ} \mathrm{N}, 34.57^{\circ} \mathrm{E} ; 12 \mathrm{~m}\right.$ above mean sea level), Badajoz in Spain $\left(38.88^{\circ} \mathrm{N},-6.83^{\circ} \mathrm{E} ; 185 \mathrm{~m}\right.$ a.m.s.l.), Bologna in Italy $\left(44.57^{\circ} \mathrm{N}, 11.53^{\circ} \mathrm{E} ; 19 \mathrm{~m}\right.$ a.m.s.l. $)$ and Eden in the UK $\left(52.26^{\circ} \mathrm{N}, 0.64^{\circ} \mathrm{E} ; 69 \mathrm{~m}\right.$ a.m.s.l.).

The daily rainfall, minimum and maximum temperatures, reference evapotranspiration $\left(\mathrm{ET}_{\mathrm{o}}\right)$ and the mean annual atmospheric carbon dioxide concentration are the input climatic data to run AquaCrop. Daily observed rainfall and temperature data (for the period 1993-2012) were extracted from the European Climate Assessment and Dataset (ECAD) (Klein Tank et al., 2002). The ECAD data undergo homogeneity testing and the missing data are filled with observations from nearby stations (i.e. within $12.5 \mathrm{~km}$ and with height differences less than $25 \mathrm{~m}$ ) (Klein Tank, 2007). Daily $\mathrm{ET}_{\mathrm{o}}$ was derived with the FAO $\mathrm{ET}_{\mathrm{o}}$ calculator (Raes, 2012), which uses the FAO Penman-Monteith equation. The evapotranspiration and precipitation of the research sites are summarized in Table 3.

Data on soil texture were extracted from the $1 \times 1 \mathrm{~km}^{2}$ resolution European Soil Database (Hannam et al., 2009). The types of soils were identified using the Soil Texture Triangle Hydraulic Properties Calculator from Saxton et al. (1986). The physical characteristics of the soils were adopted from AquaCrop, which includes a soil characteristics database of FAO. Observed soil data at one of the sites representing the humid environment (at Bologna, Italy) were shown to be comparable to the soil type and characteristics from the FAO and European Soil Database. Soil fertility stress was assumed not to occur. Regarding crop parameters, we take the default values as represented in AquaCrop, except for the maximum rooting depth for maize in Italy, which was limited to $0.7 \mathrm{~m}$ to account for the actual local conditions. Moisture supply from capillary rise to the root zone was considered only for Bologna, because the local groundwater table at the Bologna site is shallow (average $1.5 \mathrm{~m}$ ). Chemical applications, such as fertilizers and pesticides, were assumed optimal. 
Table 2. Research cases.

\begin{tabular}{|c|c|c|c|c|}
\hline $\begin{array}{l}\text { Environment } \\
\text { (location) }\end{array}$ & Soils & Type of year & Crops & Groundwater* \\
\hline $\begin{array}{l}\text { Arid } \\
\text { (Eilat, Israel) }\end{array}$ & $\begin{array}{l}\text { Loam } \\
\text { Sandy loam } \\
\text { Silty clay loam }\end{array}$ & $\begin{array}{l}\text { Dry } \\
\text { Normal } \\
\text { Wet }\end{array}$ & $\begin{array}{l}\text { Maize, } \\
\text { potato and } \\
\text { tomato }\end{array}$ & Deep \\
\hline $\begin{array}{l}\text { Semi-arid } \\
\text { (Badajoz, Spain) }\end{array}$ & $\begin{array}{l}\text { Loam } \\
\text { Sandy loam } \\
\text { Silty clay loam }\end{array}$ & $\begin{array}{l}\text { Dry } \\
\text { Normal } \\
\text { Wet }\end{array}$ & $\begin{array}{l}\text { Maize, } \\
\text { potato and } \\
\text { tomato }\end{array}$ & Deep \\
\hline $\begin{array}{l}\text { Sub-humid } \\
\text { (Bologna, Italy) }\end{array}$ & $\begin{array}{l}\text { Loam } \\
\text { Sandy loam } \\
\text { Silty clay loam }\end{array}$ & $\begin{array}{l}\text { Dry } \\
\text { Normal } \\
\text { Wet }\end{array}$ & $\begin{array}{l}\text { Maize, } \\
\text { potato and } \\
\text { tomato }\end{array}$ & Average $1.5 \mathrm{~m}$ \\
\hline $\begin{array}{l}\text { Humid } \\
\text { (Eden, UK) }\end{array}$ & $\begin{array}{l}\text { Loam } \\
\text { Sandy loam } \\
\text { Silty clay loam }\end{array}$ & $\begin{array}{l}\text { Dry } \\
\text { Normal } \\
\text { Wet }\end{array}$ & $\begin{array}{l}\text { Maize, } \\
\text { potato and } \\
\text { tomato }\end{array}$ & Deep \\
\hline
\end{tabular}

* A deep groundwater table means that capillary rise does not contribute moisture to the root zone.

Table 3. Evapotranspiration and precipitation in the four environments.

\begin{tabular}{|c|c|c|c|c|c|c|c|c|c|}
\hline \multirow[t]{4}{*}{ Environments } & \multirow[t]{3}{*}{$\mathrm{ET}_{\mathrm{o}}$} & \multirow[t]{2}{*}{ Precipitation } & \multirow{2}{*}{\multicolumn{3}{|c|}{ Precipitation }} & \multicolumn{4}{|c|}{ Actual $E$ and $\mathrm{ET}^{\mathrm{a}}$} \\
\hline & & & & & & \multicolumn{2}{|c|}{ Rain-fed } & \multicolumn{2}{|c|}{ Irrigated $^{b}$} \\
\hline & & ear average & Wet & Normal & Dry & $E$ & ET & $E$ & ET \\
\hline & \multicolumn{2}{|c|}{$\left(m m\right.$ year $\left.^{-1}\right)$} & \multicolumn{3}{|c|}{ (mm per growing season) } & \multicolumn{4}{|c|}{ (mm per growing season) } \\
\hline Arid & 2476 & 16 & 60 & 11.3 & 2.4 & 16 & 16 & 85 & 322 \\
\hline Semi-arid & 1308 & 449 & 129 & 76 & 62 & 49 & 171 & 108 & 393 \\
\hline Sub-humid ${ }^{\mathrm{c}}$ & 977 & 585 & 359 & 170 & 147 & 87 & 314 & 85 & 312 \\
\hline Humid & 688 & 722 & 834 & 665 & 657 & 79 & 282 & 128 & 390 \\
\hline
\end{tabular}

${ }^{a} E$ is evaporation in a normal year; ET is actual evapotranspiration in a normal year. ${ }^{b}$ Under conditions of full irrigation, furrow irrigation, potato, loam soil and no mulching practice. ${ }^{c}$ The groundwater table in the selected sub-humid environment is shallow, at $1.5 \mathrm{~m}$, which implies that capillary rise feeds moisture to the root zone.

\section{Results}

\subsection{Overview of experimental results}

The outcomes for ET (mm), $Y\left(\mathrm{tha}^{-1}\right)$ and consumptive WF $\left(\mathrm{m}^{3} \mathrm{t}^{-1}\right)$ in the full set of model experiments are plotted in scatter diagrams in Figs. 2a, b, c and 3. The ET- $Y$ plots in Fig. 2a, b and c show an increase in yield with increasing ET for all three crops, though there is no increase in $Y$ anymore at larger ET values. The yields for ET less than $200 \mathrm{~mm}$ in Fig. 2a, b and c are under rain-fed conditions (in semi-arid environment) and high-deficit irrigation (with drip/subsurface drip techniques), with synthetic mulching practice. In such conditions, the evaporation is almost zero and transpiration takes the lion's share of ET. The corresponding yield is very small, less than one-third of the maximum. Figure 3 illustrates the ET-WF relationship: small ET is associated with the large WFs due to the low yields resulting from water stress. The smallest WFs can be found at intermediate ET values, where yield still is not optimal, but additional ET goes along with decreasing productivity.

\subsection{Effect of the management practice on ET, $Y$ and consumptive WF}

Figure 4 illustrates the effect of the four irrigation techniques on ET and $Y$ under full, deficit and supplementary irrigation conditions for the case of potato production on loam soil in a normal year in Spain. We see that under full irrigation, moving from sprinkler to furrow and then to drip and subsurface drip irrigation, will stepwise reduce ET in quite a substantial way, while yield remains at the same high level. The reduction in ET fully refers to a reduction in the unproductive $E$; the productive $T$ remains constant. Under deficit irrigation, moving from sprinkler through furrow and drip to subsurface drip irrigation, ET will slightly decrease, while $Y$ increases. The $Y$ can increase because it is the non-productive soil evaporation component in ET that decreases, while the productive 
Table 4. The irrigation supply and ET values for supplementary, deficit and full irrigation plus rain-fed of the potato production.

\begin{tabular}{lcccc}
\hline & Rain & $\begin{array}{c}\text { Irrigation } \\
\text { supply } \\
(\mathrm{mm})\end{array}$ & ET green & ET blue \\
& 63 & 0 & 171 & 0 \\
Rain-fed & 63 & 80 & 222 & 21 \\
Supplementary irrigation & 63 & 281 & 117 & 224 \\
Deficit irrigation & 63 & 361 & 115 & 238 \\
Full irrigation & & & & \\
\hline
\end{tabular}
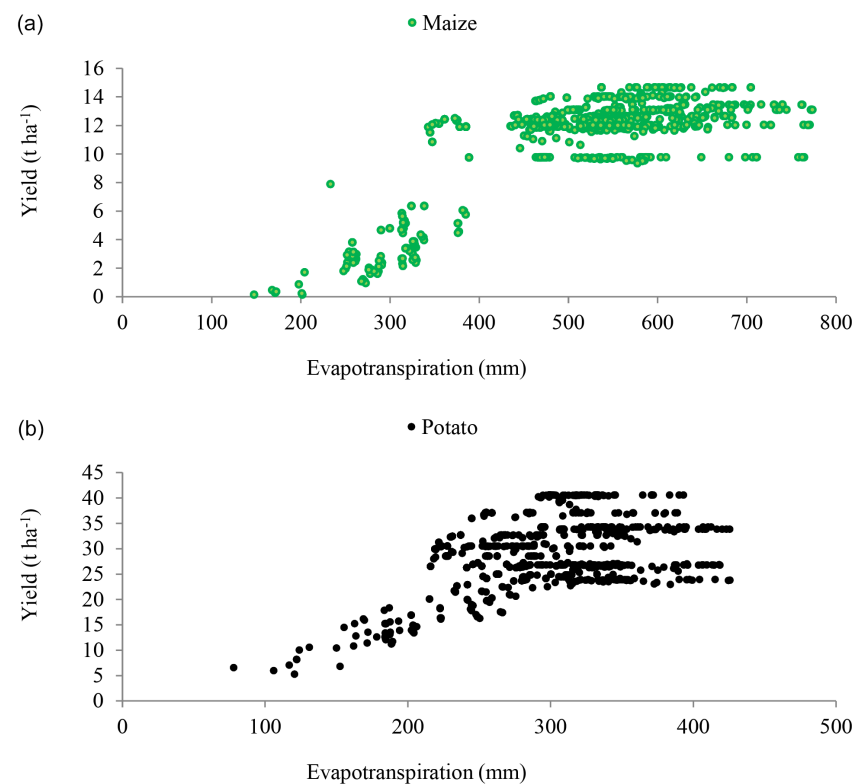

(c)

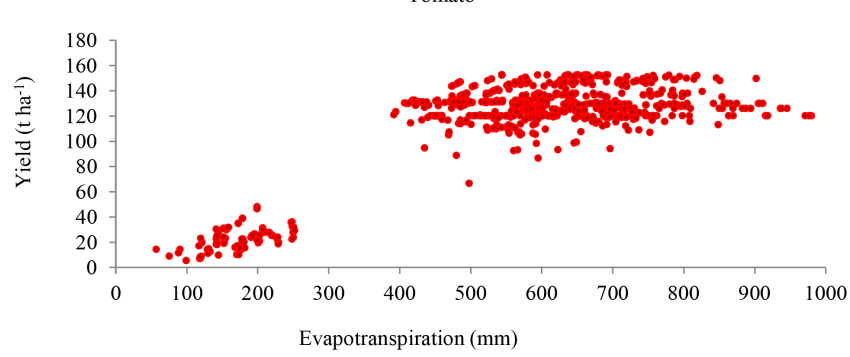

Figure 2. (a) The resultant ET and $Y$ of maize for all experiments: different management practices for all cases. (b) The resultant ET and $Y$ of potato for all experiments: different management practices for all cases. (c) The resultant ET and $Y$ of tomato for all experiments: different management practices for all cases.

transpiration component increases. Under supplementary irrigation, the irrigation technique applied affects neither ET nor $Y$, because irrigation is applied only during a short period of time (the drought period), which hardly affects ET over the growing period as a whole.

The effect of mulching on ET and $Y$ is illustrated in Fig. 5 for the same case of potato production on loam soil in a

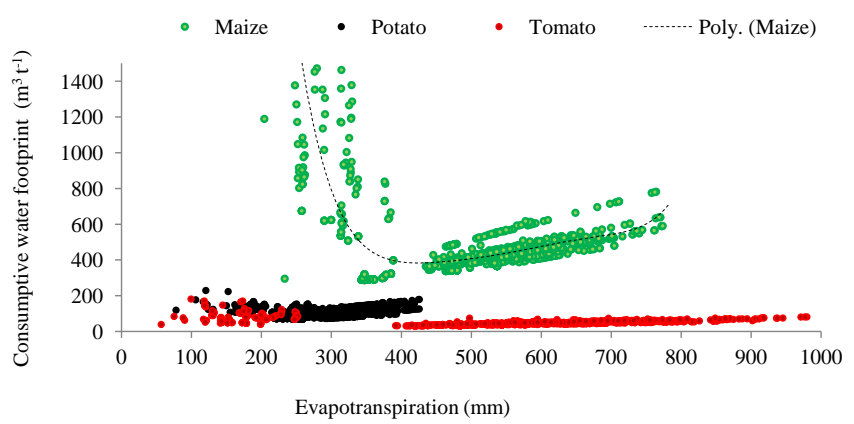

Figure 3. The resultant ET and consumptive WF for all experiments: different management practices for all cases. The dotted line is a polynomial fit to data points for maize.

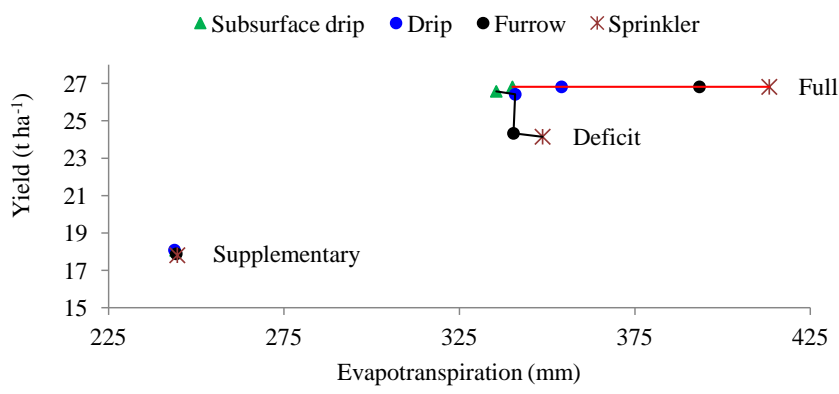

Figure 4. ET- $Y$ plot for four irrigation techniques, three strategies and no mulching practice for the case of potato on a loam soil, a normal year in a semi-arid environment (Badajoz, Spain). The lines connect cases with one particular irrigation strategy: red and black for the full and deficit irrigation strategies, respectively.

normal year in Spain. Under full irrigation, moving from no mulching through organic to synthetic mulching will reduce ET (through reduced soil evaporation), with $Y$ remaining constant. Under deficit irrigation, we observe the same trend. Under supplementary irrigation, moving from no mulching through organic to synthetic mulching, ET will slightly decrease, while $Y$ increases. The $Y$ increases because it is the non-productive $E$ that decreases, while the productive $T$ increases. Under rain-fed conditions, organic and synthetic mulching do not affect total ET much, but $E$ decreases while $T$ increases, which leads to an increase in $Y$. 


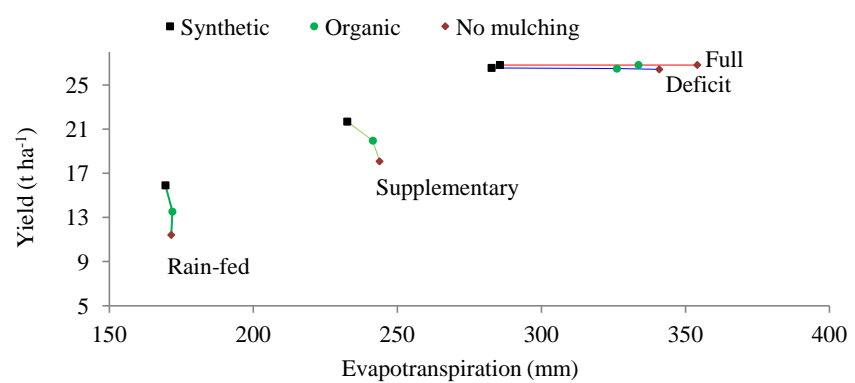

Figure 5. ET $-Y$ plot for mulching practices at rain-fed and dripirrigated fields for the case of potato in a loam soil for a normal year in a semi-arid environment (Badajoz, Spain). The lines connect cases with one particular irrigation strategy: red, blue, light green and green denote full irrigation, deficit irrigation, supplementary irrigation and rain-fed production, respectively.

The effect of different irrigation strategies on ET, $Y$ and consumptive WF is illustrated in Fig. 6 for the case of potato growth under drip irrigation on a loam soil for a normal year in Spain. Table 4 shows the amount of rainfall and irrigation supply during the growing period of potato for the same case. There is an increase in both ET and $Y$ when we move from rain-fed to supplementary irrigation and further on to deficit and full irrigation. The consumptive WF is smallest with deficit irrigation, followed by full irrigation, supplementary irrigation and finally rain-fed irrigation. The change from rain-fed to supplementary irrigation takes a modest amount of irrigation water, $80 \mathrm{~mm}$. The supplementary irrigation allowed an additional ET of $51 \mathrm{~mm}$ of green water plus $21 \mathrm{~mm}$ of blue water, making a significant impact on crop growth, thus making a small blue WF, but the resultant yield increase leads to a decrease in the overall (green plus blue) WF.

The deficit irrigation supply was $281 \mathrm{~mm}(80 \mathrm{~mm}$ reduction as compared to full irrigation). The change from full irrigation to deficit irrigation slightly reduces yield (by $1.5 \%$ ), but reduces blue ET (by $14 \mathrm{~mm}$ or $6 \%$ ), with a slight decrease in the consumptive WF as a result (by $2 \%$ ). The significant reduction in total irrigation depth in the case of the deficit irrigation thus resulted in only minor yield losses. In the case of full irrigation, blue ET and total ET are larger, but green ET is slightly smaller than in the case of deficit irrigation. This results from the fact that irrigation water saturates the soil, causing a larger fraction of rainwater to run off. Deficit irrigation thus makes more effective use of rainwater.

\subsection{Relative changes in green and blue WF compared to the reference case}

We compared the effects of all different management practices on the green and blue WF against the reference case of furrow and full irrigation and no mulching practice. We present the results in six groups, whereby each group has a specific irrigation strategy and mulching practice, with the irrigation technique as a variable. We consider the following six combinations of irrigation strategy and mulching practice:

- full irrigation (FI), no mulching practice (NoML);

- deficit irrigation (DI), no mulching practice (NoML);

- full irrigation (FI), organic mulching (OML);

- deficit irrigation (DI), organic mulching (OML);

- full irrigation (FI), synthetic mulching (SML); and

- deficit irrigation, (DI), synthetic mulching (SML).

The change in total consumptive WF from the reference for all management practices is shown in Fig. 7. Given a particular mulching practice, the largest WF is found for sprinkler, followed by furrow, drip and subsurface drip irrigation. Only for the case of full irrigation and no mulching does drip irrigation result in a smaller WF than for subsurface drip irrigation. The effect of drip and subsurface drip irrigation on consumptive WF depends on two variables limiting soil evaporation: energy and soil moisture. Under full irrigation, as can be seen in Fig. 7b, drip irrigation reduces the consumptive WF more than subsurface drip irrigation, with the largest difference in the humid environment. The reason is that energy is here the limiting factor on evaporation. Under deficit irrigation, as can be seen in Fig. 7c, subsurface drip irrigation reduces the consumptive WF more than drip irrigation, with the largest difference in the arid environment. This is explained by the fact that moisture is now the limiting factor on evaporation.

Compared to the reference case of no mulching, organic mulching substantially reduces the consumptive WF, and synthetic mulching even further. In the case of full irrigation, organic mulching results, on average, in an additional consumptive WF reduction compared to no mulching of $17 \%$ with sprinkler, $13 \%$ with furrow, $7 \%$ with drip and $11 \%$ with subsurface drip irrigation. In the case of deficit irrigation, these additional reductions are slightly lower: $14 \%$ with sprinkler, $11 \%$ with furrow, $6 \%$ with drip and $7 \%$ with subsurface drip irrigation. Considering drip and subsurface drip irrigation, synthetic mulching results, on average, in an additional consumptive WF reduction of $10 \%$ compared to organic mulching.

Figure 8 shows the average changes in consumptive WF for management practices, specified per type of environment. The average reduction in the consumptive WF is $8-10 \%$ if we change from the reference to drip or subsurface drip irrigation, $13 \%$ when changing from the reference to organic mulching, 17-18\% when moving to drip or subsurface drip irrigation in combination with organic mulching, and $28 \%$ when shifting to drip or subsurface drip irrigation with synthetic mulching. All before-mentioned reductions increase by one or a few per cent when moving from full to deficit 

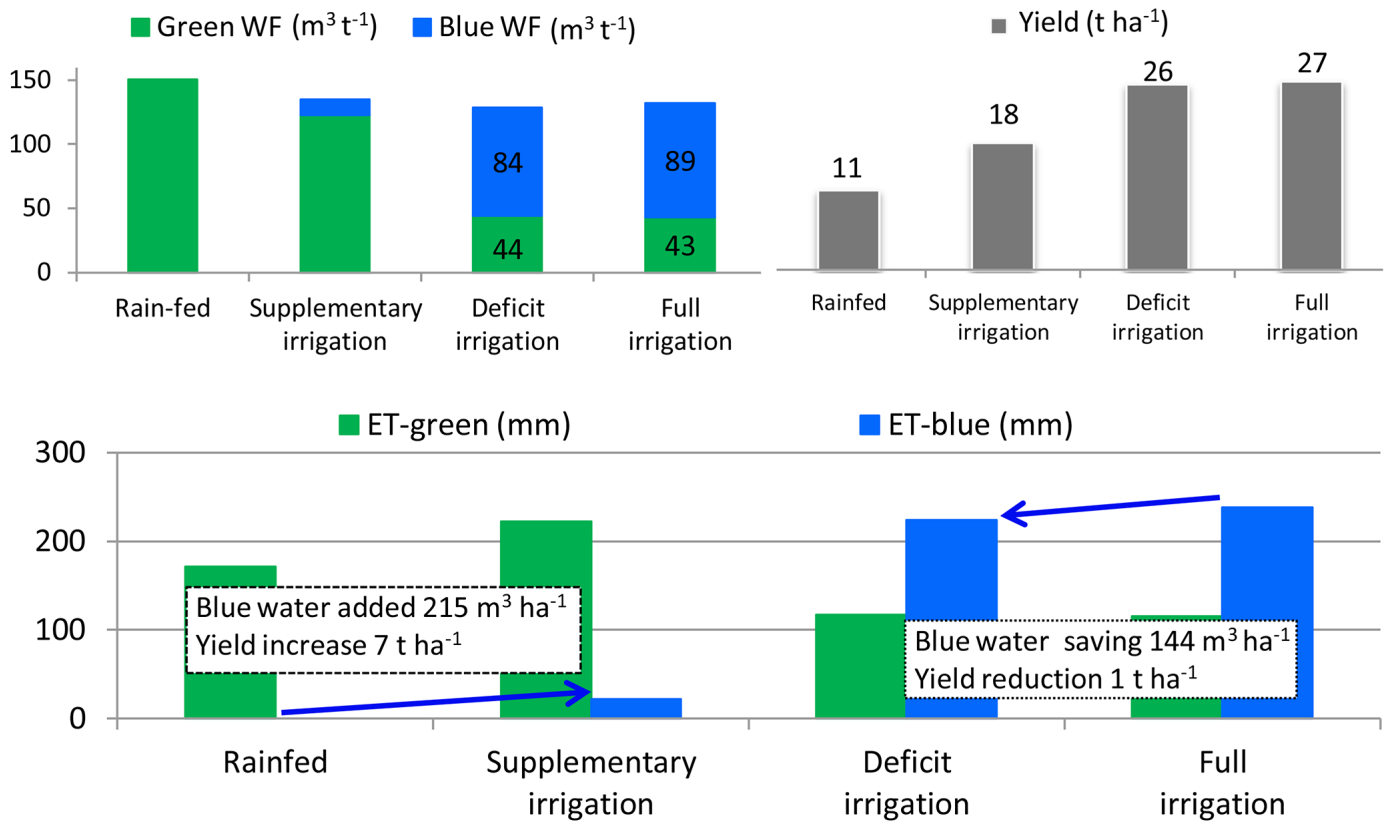

Figure 6. ET, $Y$ and WF under different irrigation strategies for the case of potato production under drip irrigation on loam soil in a normal year in a semi-arid environment (Badajoz, Spain).

irrigation. In our case of the sub-humid environment, with the selected location in Italy having shallow groundwater, we find relatively small WF reductions when we have no mulching, because capillary rise keeps feeding the soil moisture content, resulting in continued soil evaporation.

The average change in green, blue and total consumptive WF from the reference for all management practices is presented in Fig. 9. Relative changes in blue WF are always larger than relative changes in the total consumptive WF, while the relative changes in green WF are always smaller. In other words, when management practices reduce the total consumptive WF, they do so particularly by reducing the blue WF and to a lesser extent by reducing the green WF. The latter even increases in the practice that combines sprinkler irrigation without mulching. In all cases, overall consumptive WF reduction goes together with an increasing green/blue ratio for the WF of a crop. Given a certain irrigation technique and mulching practice, deficit irrigation will always reduce the blue WF of the crop, when compared to the practice of full irrigation.

\section{Discussion}

An interesting result from this study is that sprinkler irrigation does have a larger consumptive WF in $\mathrm{m}^{3} \mathrm{t}^{-1}$ (i.e. smaller water productivity in $\mathrm{tm}^{-3}$ ) than furrow irrigation, while sprinkler irrigation is known to have larger so-called irrigation efficiency compared to furrow irrigation (Brouwer et al., 1988). With sprinkler irrigation, a larger soil surface is wetted than in the case of furrow irrigation (Ali, 2011). Thus, for an equal level of production, sprinkler irrigation results in larger ET (because of larger soil evaporation) and consumptive WF than furrow irrigation. Compared to sprinkler, furrow irrigation has higher percolation and runoff fluxes, variables that define irrigation efficiency. These fluxes return to the catchment and are not a loss from the system and therefore not considered to contribute to consumptive WF (Hoekstra et al., 2011).

The findings of this study indicate that subsurface drip irrigation is most useful for consumptive WF reduction in the arid environment. The reason is that with subsurface drip irrigation, moisture content in the topsoil will be smaller and thus limit soil evaporation. In the other environments, the difference between drip and subsurface drip irrigation is minor. With full irrigation in the humid environment, subsurface drip irrigation even results in a larger consumptive WF than in the case of drip irrigation. We believe that these results are plausible, as they are consistent with findings from Dehghanisanij and Kosari (2011), who explain that the net energy available for soil evaporation for SSD irrigation is larger than for drip. The reason is that drip irrigation produces a cooling effect on the topsoil, reducing the energy available for evaporation, and thus limiting soil evaporation. This is due to heat convection or a higher soil heat flux along with droplets of water moving from the soil surface into the soil in the case of drip. Therefore, with full irrigation in the humid environment where the net radiation energy for evaporation is limiting, drip results in smaller consumptive WF than SSD. 


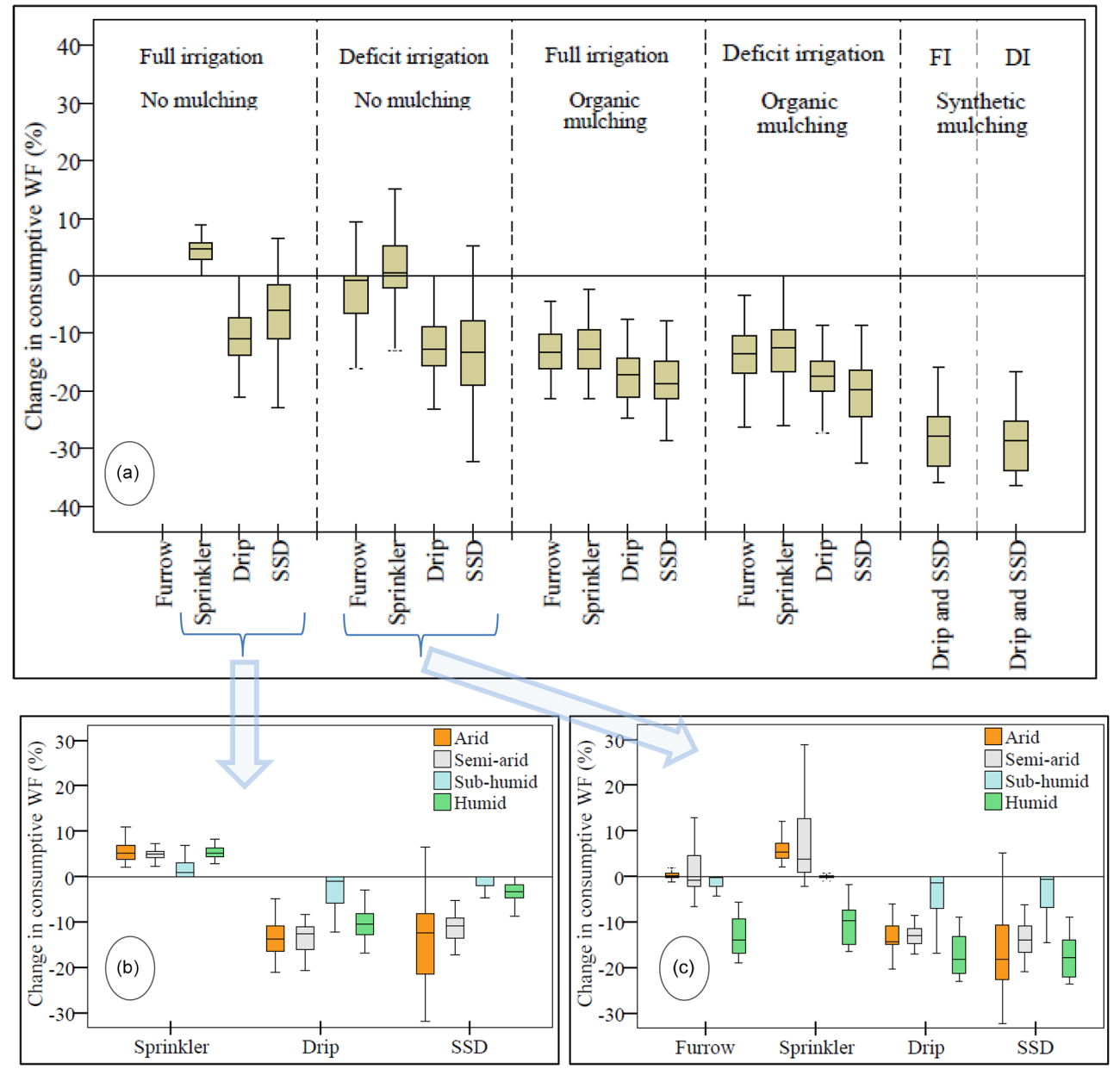

Figure 7. Change in consumptive WF from the reference for all management practices. The range for each management practice represents the variation of changes found for the various cases. The upper and lower ends of the whiskers are the largest and smallest changes found; $50 \%$ of the cases fall within the range represented by the upper and lower values of the box. The line within the box represents the change in the median case. (a) gives an overview of all management practices; (b) and (c) zoom in for the practices of full and deficit irrigation, respectively, without mulching, showing specific WF changes per type of environment. SSD stands for subsurface drip, FI for full irrigation, DI for deficit irrigation, NoML for mulching practice, OML for organic mulching and SML for synthetic mulching.

The ET vs. $Y$ plots made based on our model experiment results (Fig. 2a, b and c) are comparable with the production function in earlier studies (Amarasinghe and Smakhtin, 2014; Wichelns, 2015). Amarasinghe and Smakhtin (2014) derived the production function from observed data under various agro-ecological conditions, water availability constraints and management practices.

Net irrigation supply simulated using AquaCrop for our semi-arid case in Spain is consistent with the values reported by the Guadiana River basin authority. We simulate net irrigation supply in the range of $200-600 \mathrm{~mm}$ for full irrigation under different irrigation techniques and soil types for a normal year for the case of tomato in our Spanish site, which is within the observed range of $150-650 \mathrm{~mm}$ as reported by the Guadiana River basin authority (CHG, 2013). Our simulated values for net irrigation supply for the same site are also consistent with the reported values for maize and potato. The simulated net irrigation supply for potato is in the range of $180-350 \mathrm{~mm}$ and the reported range is $150-380 \mathrm{~mm}$. For maize we find a simulated range of $450-600 \mathrm{~mm}$ and a reported range of $450-630 \mathrm{~mm}$.

The AquaCrop model has been validated for herbaceous crops at diverse locations in different environments (Steduto et al., 2011). It is designed to be applicable under various climate and soil conditions, with no need for calibration once it has been parameterized for a specific crop species (Hsiao et al., 2011). This study is made for crops that had already been parameterized in AquaCrop. The sensitivity of AquaCropsimulated yields to model parameters, under diverse environmental conditions, was studied by Vanuytrecht et al. (2014). That study shows that the parameters describing crop responses to water stress were not often among those show- 


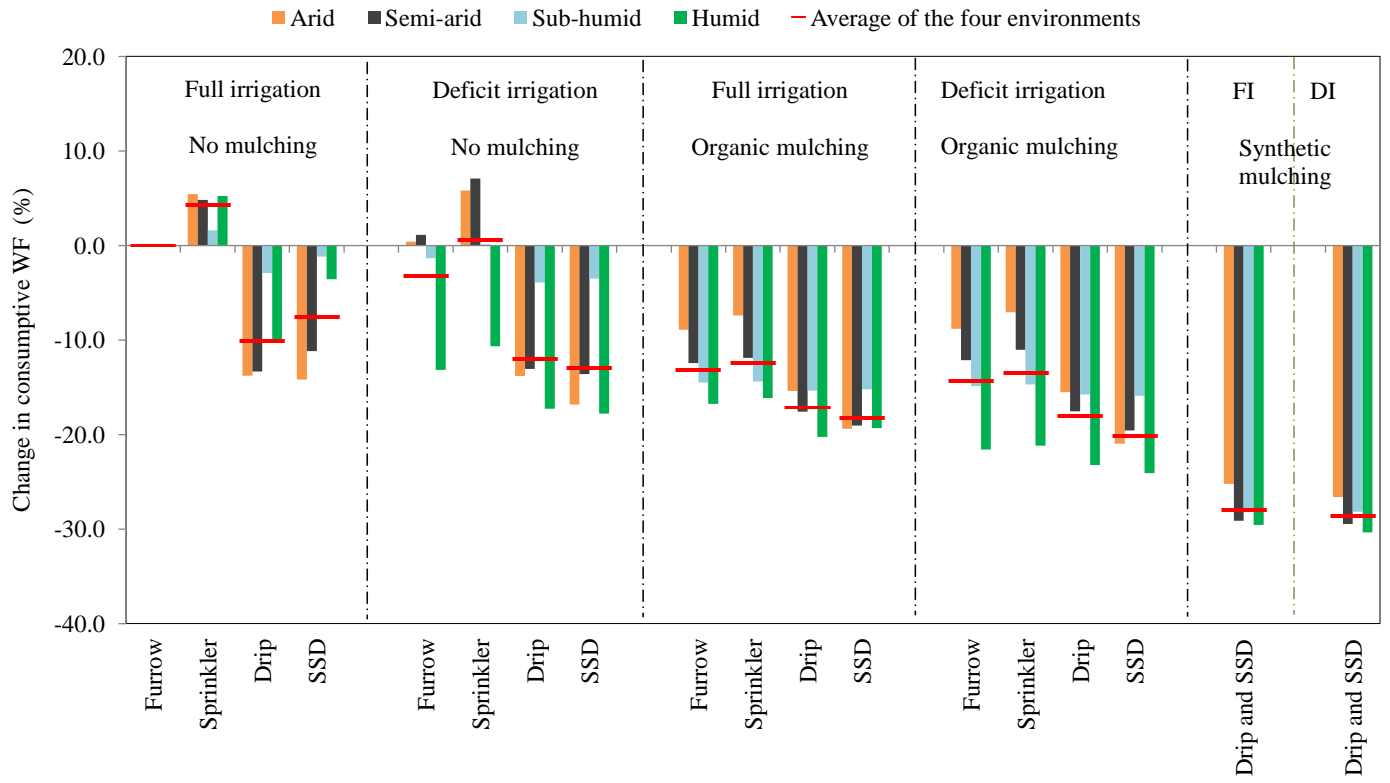

Figure 8. Average change in consumptive WF from the reference for all management practices, specified for the four types of environment. The horizontal red lines represent averages for the four environments. SSD stands for subsurface drip, FI for full irrigation, DI for deficit irrigation, NoML for mulching practice, OML for organic mulching and SML for synthetic mulching.

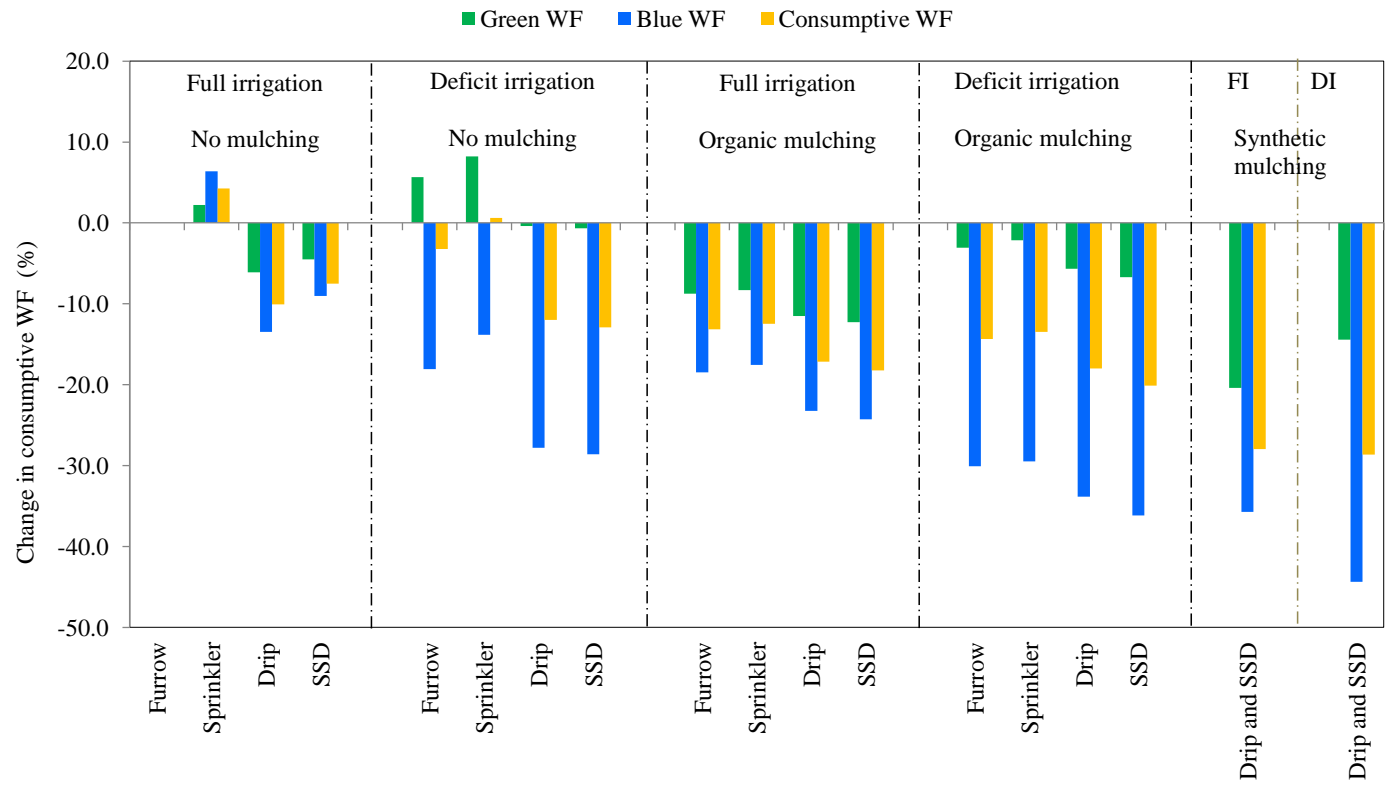

Figure 9. Average change in green, blue and total consumptive WF from the reference for all management practices. SSD stands for subsurface drip, FI for full irrigation, DI for deficit irrigation, NoML for mulching practice, OML for organic mulching and SML for synthetic mulching.

ing highest sensitivity. The particular root and soil parameters indeed need attention during calibration. We did not perform a specific sensitivity analysis for these inputs or a specific uncertainty analysis propagating parameter uncertainty through the model, which both would be interesting. The current analysis, however, already shows the robustness of the AquaCrop-simulated effects of irrigation method, irrigation strategy and mulching for a large set of conditions for soil, crop, climate and weather. Together with the sensitivity results of Vanuytrecht et al. (2014), we believe the overall evidence to support the conclusions is strong. 
We note that AquaCrop has inherent limitations, including for instance the neglect of lateral water flows in the field, the inability to simulate the effects of nutrient limitation, fertilizer application, the effect of organic mulching on the organic content of the soil and decomposition of organic materials, interception losses from sprinklers and the inability to define the depth at which subsurface drip irrigation takes place. These limitations put a disclaimer on the results of our study, but we believe that the results of this study can provide a useful reference for similar future studies with other models. We see the need for further validation of our model results with field experiments, but this is costly and will generally need to focus on varying just a few management practices under a limited number of cases. In our model experimental set-up, we varied a large number of variables (irrigation techniques, strategies, mulching practices, environments, soils, crops, dry versus wet years) in all possible combinations, which is impossible in a field experiment.

By focussing on the effect of irrigation and mulching, we excluded from this study the effects of other agricultural practices such as the use of agrochemicals and tillage. Besides, by focussing on management practices at field level, we have excluded measures that could be applied to reduce consumptive WF in the stages before irrigation water is applied to the field, like measures to reduce evaporative losses from storage reservoirs and distribution canals.

\section{Conclusions}

Water footprint reduction in irrigated crop production is the way forward for efficient and sustainable water resource use. This paper provides the first detailed and comprehensive study regarding the potential for reducing the consumptive WF of a crop at field level by changing management practice such as irrigation technique, irrigation strategy and mulching practice. The effects of the various combinations of irrigation technique and strategy and mulching practice were compared to the reference of furrow and full irrigation without mulching. We found the largest WF reduction (average of $35 \%$ for different soils and years) for tomato production under drip or subsurface drip irrigation with synthetic mulching under the semi-arid environment. If we consider all the cases of drip or subsurface drip irrigation with synthetic mulching, including all crops and environments, we find an average consumptive WF reduction of $28 \%$ for full irrigation and $29 \%$ for deficit irrigation. In the latter case, the corresponding blue WF reduction is $44 \%$ and the green WF reduction $14 \%$.

- Irrigation techniques and strategies and mulching practices can be ordered based on their potential to reduce the blue or total consumptive WF, from low to high potential.
- Irrigation techniques: sprinkler, furrow, drip/subsurface drip irrigation.

- Irrigation strategies: rain-fed, supplementary irrigation, full irrigation, deficit irrigation.

- Mulching practices: no mulching, organic mulching, synthetic mulching.

The percentage of blue WF reduction is always larger than the percentage of total consumptive WF reduction. Generally, reduction in the total consumptive WF includes a reduction in the green WF as well. However, when we move from full to deficit irrigation (other things equal), the green WF will increase. Note still that deficit irrigation reduces the blue WF and the overall consumptive WF. The increased blue water and overall water productivity achieved through deficit irrigation thus slightly reduces the green water productivity.

This study can be used as a reference in future studies regarding the potential effect of management practices on the consumptive WF. The results can contribute to making strategic choices to achieve greater crop water productivity and setting WF benchmarks for crop production. The findings of this paper can be used in subsequent studies at basin scale, with the help of an appropriate model that can simulate the effects of additional management practices like fertilizer application as well, to study the possible water saving (while producing the same crop amount) and water scarcity reduction at basin scale or the possible crop production increase without increasing water use. The ranking of irrigation methods, irrigation strategies and mulching practices as provided in this paper gives a first indication of what can be done to increase water productivity and the potential gains that can be achieved through certain combinations of practices. Formulations are still made with caution as relevant considerations such as fertilizer application and associated grey water footprints and possible economic trade-offs are outside the scope of the present paper. However, although our conclusions regarding the effectiveness of different irrigation techniques and strategies and mulching practices are generally valid, we must be careful in translating the general findings to very specific cases, because the precise WF reduction that can be achieved in a particular case will always be contextspecific. 


\section{Appendix A: Illustration of the simulation of green and} blue soil moisture content

Initial soil moisture was quantified for the four environments as follows: $10 \%$ green and $90 \%$ blue for the arid environment; $35 \%$ green and $65 \%$ blue for the semi-arid environment; $48 \%$ green and $37 \%$ blue from capillary rise, and $15 \%$ blue from irrigation water for the sub-humid environment (with shallow groundwater); and $98 \%$ green and $2 \%$ blue for the humid environment.

Figure A1 illustrates the development of green and blue soil water content over the growing period as simulated with AquaCrop and our additional module partitioning the soil water content and fluxes into green and blue components.

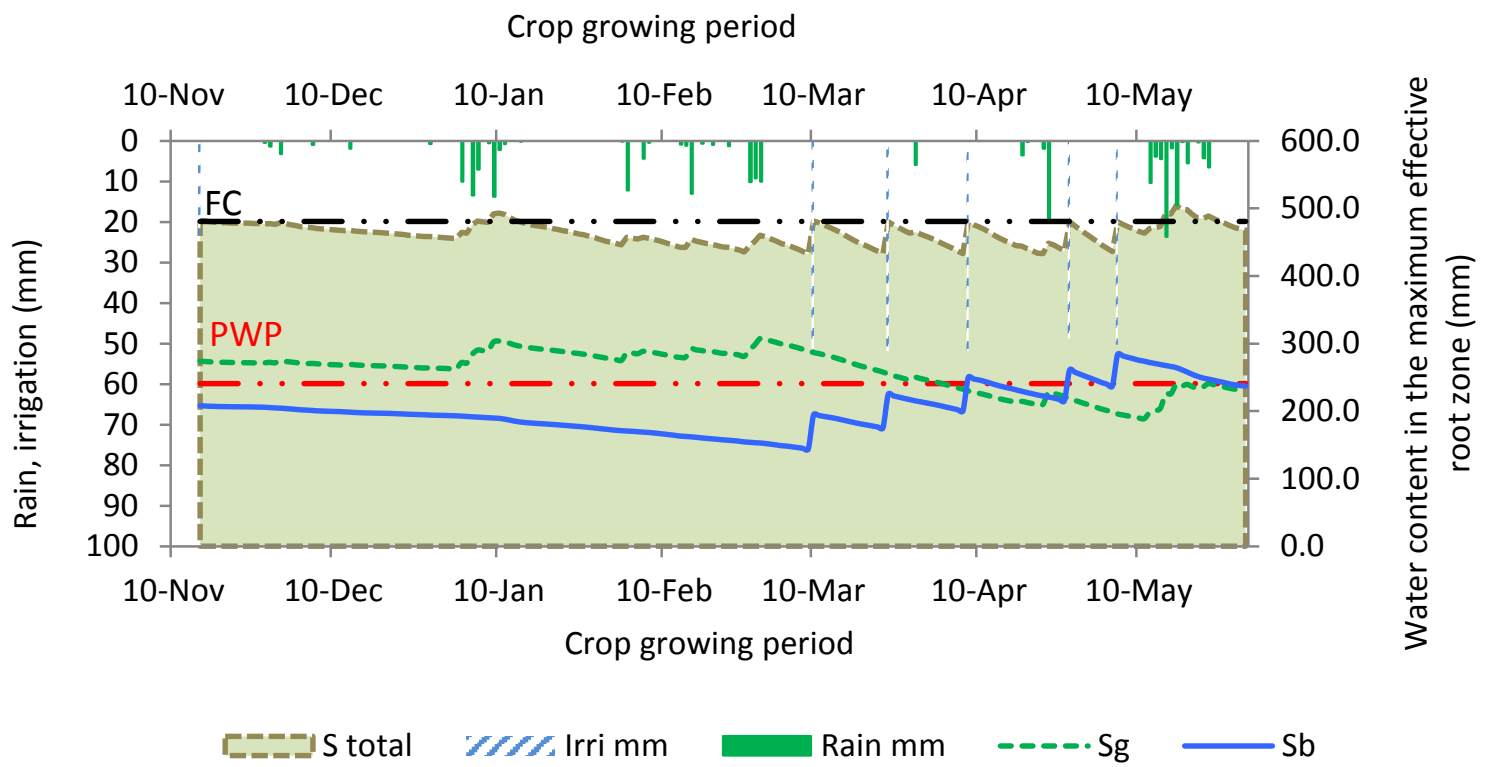

Figure A1. The development of the green $\left(S_{\mathrm{g}}\right)$ and blue $\left(S_{\mathrm{b}}\right)$ soil water content over the growing period for the case of maize on a loam soil and a normal year at Badajoz in Spain. The symbol S represents total soil moisture, Irri irrigation, FC field capacity, and PWP permanent wilting point. 
Acknowledgements. This research was conducted as part of EU-FP7-funded project FIGARO. The authors wish to thank all consortium partners. We thank Adriano Battilani, CER in Italy, and Julian Gruzelier, Eden Irrigation in the UK, for sharing data and background information on their respective research sites. Thanks to Dirk Raes, Division of Soil and Water Management, KU Leuven University in Belgium, for the useful discussion and advice in using AquaCrop. The paper was partially developed within the framework of the Panta Rhei Research Initiative of the International Association of Hydrological Sciences (IAHS).

Edited by: N. Romano

\section{References}

Afshar, A. and Neshat, A.: Evaluation of Aqua Crop computer model in the potato under irrigation management of continuity plan of Jiroft region, Kerman, Iran, Int. J. Adv. Biol. Biom. Res., 1, 1669-1678, 2013.

Al-Said, F. A., Ashfaq, M., Al-Barhi, M., Hanjra, M. A., and Khan, I. A.: Water productivity of vegetables under modern irrigation methods in Oman, Irrig. Drain., 61, 477-489, 2012.

Ali, M. H.: Water Application Methods, in: Practices of Irrigation \& On-farm Water Management, Springer, New York, USA, 35-63, 2011.

Allen, R., Pereira, L., Raes, D., and Smith, M.: Crop evapotranspiration. FAO irrigation and drainage paper 56, FAO, Rome, Italy, 1998.

Amarasinghe, U. A. and Smakhtin, V.: Water productivity and water footprint: misguided concepts or useful tools in water management and policy?, Water Int., 39, 1000-1017, 2014.

Bakhsh, A., Hussein, F., Ahmad, N., Hassan, A., and Farid, H. U.: Modeling deficit irrigation effects on maize to improve water use efficiency, Pak. J. Agr. Sci., 49, 365-374, 2012.

Brouwer, C., Prins, K., Kay, M., and Heibloem, M.: Irrigation water management: irrigation methods. Training manual no 5, Food and Agriculture Organization of the United Nations, Rome, Italy, 1988.

CHG - Confederación Hidrográfica del Guadiana: Plan Hidrológico de la parte española de la demarcación hidrográfica del Guadiana, Memoria, Summary of the Guadiana River Basin Management Plan, Guadiana River Basin Authority, Spanish Ministry of the Environment and Rural and Marine Affairs, Badajoz, Spain, 2013.

Dehghanisanij, H. and Kosari, H.: Evapotranspiration partitioning in surface and sbsurface drip irrigation systems, INTECH Open Access Publisher, Rijeka, Croatia, 2011.

English, M.: Deficit irrigation. I: Analytical framework, J. Irrig. Drain. E., 116, 399-412, 1990.

Falkenmark, M. and Rockström, J.: The new blue and green water paradigm: Breaking new ground for water resources planning and management, J. Water Resour. Plann. Manage., 3, 129-132, 2006.

FAO: Annex I Crop parameters, AquaCrop reference manual, Food and Agriculture Organization of the United Nations, Rome, Italy, 2012.

Fereres, E. and Soriano, M. A.: Deficit irrigation for reducing agricultural water use, J. Exp. Bot., 58, 147-159, 2007.
Fereres, E., Walker, S., K. Heng, L., C. Hsiao, T., Steduto, P., Raes, D., Izzi, G., Asseng, S., and R. Evett, S.: AquaCrop applications, Food and Agriculture Organization of the United Nations, Rome, Italy, 2012.

Geerts, S. and Raes, D.: Deficit irrigation as an on-farm strategy to maximize crop water productivity in dry areas, Agr. Water Manage., 96, 1275-1284, 2009.

Gleick, P. H.: Global freshwater resources: soft-path solutions for the 21 st century, Science, 302, 1524-1528, 2003.

Hannam, J. A., Hollis, J. M., Jones, R. J. A., Bellamy, P. H., Hayes, S. E., Holden, A., Liedekerke, M. H., and Montanarella, L.: SPE-2: The soil profile analytical database for Europe, Beta Version 2.0, http://eusoils.jrc.ec.europa.eu/projects/spade/ spade2.html (last access: June 2014), 2009.

Hoekstra, A. Y.: The Water Footprint of Modern Consumer Society, Routledge, London, UK, 2013.

Hoekstra, A. Y. and Mekonnen, M. M.: The water footprint of humanity, P Natl Acad Sci USA, 109, 3232-3237, 2012.

Hoekstra, A. Y., Chapagain, A. K., Aldaya, M. M., and Mekonnen, M. M.: The Water Footprint Assessment Manual: Setting the Global Standard, Earthscan, London, UK, 2011.

Hsiao, T., Fereres, E., Steduto, P., and Raes, D.: AquaCrop parameterization, calibration, and validation guide, Crop yield response to water, Irrig. Drain. Pap., 66, 70-87, 2011.

Igbadun, H. E., Ramalan, A. A., and Oiganji, E.: Effects of regulated deficit irrigation and mulch on yield, water use and crop water productivity of onion in Samaru, Nigeria, Agr. Water Manage., 109, 162-169, 2012.

Jalota, S. and Prihar, S. S.: Reducing soil water evaporation with tillage and straw mulching, Eurospan Group, London, UK, 1998.

Jinxia, Z., Ziyong, C., and Rui, Z.: Regulated deficit drip irrigation influences on seed maize growth and yield under film, Proc. Engin., 28, 464-468, 2012.

Jiru, M. and Van Ranst, E.: Increasing water productivity on Vertisols: implications for environmental sustainability, J. Sci. Food Agr., 90, 2276-2281, 2010.

Klein Tank, A.: EUMETNET/ECSN optional programme: European Climate Assessment \& Dataset (ECA\&D) Algorithm Theoretical Basis Document (ATBD), version 4, Royal Netherlands Meteorological Institute KNMI, 2007.

Klein Tank, A., Wijngaard, J., Können, G., Böhm, R., Demarée, G., Gocheva, A., Mileta, M., Pashiardis, S., Hejkrlik, L., and KerrnHansen, C.: Daily dataset of 20 century surface air temperature and precipitation series for the European Climate Assessment, Int. J. Climatol., 22, 1441-1453, 2002.

Mao, L. L., Zhang, L. Z., Li, W. Q., van der Werf, W., Sun, J. H., Spiertz, H., and Li, L.: Yield advantage and water saving in maize/pea intercrop, Field Crop Res., 138, 11-20, 2012.

McCraw, D. and Motes, J. E.: Use of plastic mulch and row covers in vegetable production, Cooperative Extension Service, Oklahoma State University, USA, OSU Extension Facts, 6034, 1991.

Molden, D., Oweis, T., Steduto, P., Bindraban, P., Hanjra, M. A., and Kijne, J.: Improving agricultural water productivity: Between optimism and caution, Agr. Water Manage., 97, 528-535, 2010.

Ogban, P. I., Ogunewe, W. N., Dike, R. I., Ajaelo, A. C., Ikeata, N. I., Achumba, U. E., and Nyong, E. E.: Effect of tillage and mulching practices on soil properties and growth and yield of 
Cowpea (Vigna Unguiculata(L), Walp) in southeastern Nigeria, Agro-Sci., 7, 118-128, 2008.

Oweis, T. and Hachum, A.: Water harvesting and supplemental irrigation for improved water productivity of dry farming systems in West Asia and North Africa, Agr. Water Manage., 80, 57-73, 2006.

Oweis, T., Hachum, A., and Kijne, J.: Water harvesting and supplemental irrigation for improved water use efficiency in dry areas, International Water Management Institute, Colombo, Sri Lanka, 1999.

Perry, C.: Efficient irrigation; Inefficient communication; Flawed recommendations, Irrig. Drain., 56, 367-378, 2007.

Perry, C., Steduto, P., Allen, R. G., and Burt, C. M.: Increasing productivity in irrigated agriculture: Agronomic constraints and hydrological realities, Agr. Water Manage., 96, 1517-1524, 2009.

Qiu, Y. F. and Meng, G.: The Effect of water saving and production increment by drip Irrigation schedules, Third International Conference on Intelligent System Design and Engineering Applications (ISDEA), Hong Kong, 16-18 January 2013.

Raes, D.: The ETo Calculator. Reference Manual Version 3.2, Food and Agriculture Organization of the United Nations, Rome, Italy, 2012.

Raes, D., Steduto, P., Hsiao, T. C., and Fereres, E.: AquaCrop-The FAO Crop Model to Simulate Yield Response to Water: II. Main Algorithms and Software Description, Agron. J., 101, 438-447, 2009.

Raes, D., Steduto, P., Hsiao, T. C., and Fereres, E.: Reference Manual AquaCrop plug-in program, Food and Agriculture Organization of the United Nations, Land and Water Division, Rome, Italy, 2011.

Raes, D., Steduto, P., Hsiao, T. C., and Fereres, E.: Chapter 3 AquaCrop, Version 4.0, Food and Agriculture Organization of the United Nations, Land and Water Division, Rome, Italy, 2012.

Raes, D., Steduto, P., and Hsiao, T. C.: Reference manual, Chapter 2, AquaCrop model, Version 4.0, Food and Agriculture Organization of the United Nations, Rome, Italy, 2013.

Rashidi, M., and Keshavarzpour, F.: Effect of different irrigation methods on crop yield and yield components of cantaloupe in the arid lands of Iran, World Appl. Sci. J., 15, 873-876, 2011.

Ritchie, J.: Model for predicting evaporation from a row crop with incomplete cover, Water Resour. Res., 8, 1204-1213, 1972.

Saad, A. M., Mohamed, M. G., and El-Sanat, G. A.: Evaluating AquaCrop model to improve crop water productivity at North Delta soils, Egypt, Adv. Appl. Sci. Res., 5, 293-304, 2014.

Saxton, K., Rawls, W. J., Romberger, J., and Papendick, R.: Estimating generalized soil-water characteristics from texture, Soil Sci. Soc. Am. J., 50, 1031-1036, 1986.
Shaxson, F. and Barber, R.: Optimizing soil moisture for plant production. The significance of soil porosity, Food and Agriculture Organization of the United Nations, Rome, Italy, 2003.

Steduto, P., Hsiao, T. C., and Fereres, E.: On the conservative behavior of biomass water productivity, Irrig. Sci., 25, 189-207, 2007.

Steduto, P., Hsiao, T. C., Raes, D., and Fereres, E.: AquaCrop-The FAO Crop Model to Simulate Yield Response to Water: I. Concepts and Underlying Principles, Agron. J., 101, 426-437, 2009 a.

Steduto, P., Raes, D., Hsiao, T., Fereres, E., Heng, L., Howell, T. Evett, S., Rojas-Lara, B., Farahani, H., Izzi, G., Oweis, T., Wani, S., Hoogeveen, J., and Geerts, S.: Concepts and Applications of AquaCrop: The FAO Crop Water Productivity Model, in: Crop Modeling and Decision Support, edited by: Cao, W., White, J., and Wang, E., Springer, Berlin, Germany, 175-191, 2009b.

Steduto, P., Hsiao, T. C., Raas, M., Fereres, E., G., Izzi, G., Heng, L., and Hoogeveen, J.: Performance review of AquaCrop - The FAO crop-water productivity model, ICID 21 st International Congress on Irrigation and Drainage, 15-23 October 2011, Tehran, Iran, R.56.2.19, 2011.

Steduto, P., Hsiao, T. C., Raes, D., and Fereres, E.: Crop yield response to water, Food and Agriculture Organization of the United Nations Italy, Rome, 2012.

Tadayon, M., Ebrahimi, R., and Tadayyon, A.: Increased water productivity of wheat under supplemental irrigation and nitrogen application in a semi-arid region, J. Agr. Sci. Technol., 14, 9951003, 2012.

Vanuytrecht, E., Raes, D., and Willems, P.: Global sensitivity analysis of yield output from the water productivity model, Environ. Modell. Software, 51, 323-332, 2014.

Wichelns, D.: Water productivity and food security: considering more carefully the farm-level perspective, Food Sec., 7, 247-260, 2015.

Zhao, G. Q., Zhu, Z. X., Zheng, Y. F., and Fang, W. S.: Water-saving techniques in Chinese agriculture - water-saving irrigation and straw mulching for winter wheat, P. Soc. Photo-Opt. Ins., 5153, 195-199, 2003.

Zhou, J. B., Wang, C. Y., Zhang, H., Dong, F., Zheng, X. F., Gale, W., and Li, S. X.: Effect of water saving management practices and nitrogen fertilizer rate on crop yield and water use efficiency in a winter wheat-summer maize cropping system, Field Crop Res., 122, 157-163, 2011. 